three cardinal principles in my Theory of Universal Algebra, between which and Newton's Three Laws of Motion I considered that I had succeeded in establishing a one-to-one correspondence.

Athenæum Club, September 22.

\section{THE BRITISH ASSOCIATION. SECTION H.}

\section{ANTHROPOLOGY.}

Opening Address by Lieutenant-General Pitt-Rivers, D.C.L., F.R.S., F.G.S., F.S.A., President of THE Section.

HAVING been much occupied up to within the last week in my own special branch of anthropology, and in bringing out the second volume of my excavations in Dorsetshire, which I wished to have ready for those who are interested in the subject on the occasion of this meeting, I regret that I have been unable to prepare an address upon a general subject as I could have wished to do, and am compelled to limit my remarks to matters on which I have been recently engaged. Also, I wish to make a few observations on the means to be taken to promulgate anthropological knowledge and render it available for the education of the masses.

Taking the last-mentioned subject first, I will commence with anthropological museums, to which I have given attention for many years. In my judgment, an institution that is dedicated to the Muses should be something more than a store, it should have some backbone in it. It should be in itself a means of conveying knowledge, and not a mere repository of objects from which knowledge can be culled by those who know where to look for it. A national museum, created and maintained at the public expense, should be available for public instruction, and not solely a place of reference for savants.

I do not deny the necessity that exists for museum stores for the use of students, but I maintain that, side by side with such stores, there should in these days exist museums instructively arranged for the ben+fit of those who have no time to study, and for whom the practical results of anthropological and other, scientific investigations are quite as important as for savants.

The one great feature which it is desirable to emphasize in connection with the exhibition of archacological and ethnological specimens is evolution. To impress upon the mind the continuity and historical sequence of the arts of life, is, without doubt, one of the most important lessons to be inculcated. It is only of late years that the development of social institutions has at all entered into the design of educational histories. And the arts of life. so far as I am aware, have never formed part of any educational series. Yet as a study of evolution they are the most important of all, because in them the connecting link: between the various phases of development can be better displayed.

The relative value of any subject for this purpose is not in proportion to the interest which attaches to the subject in the abstract. Laws, customs, and institutions may perhaps be regarded as of greater importance than the arts of life, but for anthropological purposes they are of less value, because in them previously to the introduction of writing, the different phases of development, as soon as they are superseded by new ideas, are entirely lost and cannot be reproduced except in imagination. Whereas in the arts of life, in which ideas are embodied in material forms, the connecting links are in many cases preserved, and can be replaced in their proper sequence by means of antiquities.

For this reason the study of the arts of life ought always to precede the study of social evolution, in order that the studen may learn to make allowance for missing links, and to avoid sophisms and the supposition of laws and tendencies which have no existence in reality.

To ascertain the true causes for all the phenomena of human life is the main object of anthropological research, and it is obvious that this is better done in those branches in which the continuity is best preserved.

In the study of natural history, existing animals are regarded as present phases in the development of species, and their value to the biological student depends, not so much on their being of the highest organism, as on the palæontological sequence by which their history is capable of being established. In the same way existing laws, institutions, and arts, wherever they are found in their respective stages of perfection, are to be regarded simply as existing strata in the development of human life, and their value from an anthropological point of view depends on the facilities they afford for studying their history.

If I am right in this view of the matter, it is evident that the arts of life are of paramount importance, because they admit of being arranged in cases by means of antiquities in the order in which they actually occurred, and by that means they serve to illustrate the development of other branches which cannot be so arranged, and the continuity of which is therefore not open to visual demonstration for the benefit of the unlearned.

It is now considerably over thirty years since I first began to pay attention to this subject. Having been employed in experimenting with new inventions in fire-arms, submitted to H.M. Government in $1852-53$, I drew up in 1858 a paper which was published in the United Service Journal, showing the continuity observable in the various ideas submitted for adoption in the army at that time.

Later, in $1867-68-69$, I published three papers, which, in order to adapt them to the institution at which they were read, I called "Lectures on Primitıve Warfare," but which, in reality, were treatises on the development of primitive weapons, in which it was shown how the earliest weapons of savages arose from the selection of natural forms of sticks and stones, and were developed gradually into the forms in which they are now used. I al o traced the development of the forms of imple:nents of the Bronze Age and their transition into those of the Iron Age. These papers were followed by others on the same subject read at the Royal Institution and elsewhere, relating to the develop. ment of special branches, such as early modes of navigation, forms of ornament, primitive locks and keys, the distribution of the bow, and its development into what I termed the composite bow in Asia and America, and other subjects.

Meanwhile I had formed a museum, in which the objects to which the papers related were arranged in developmental order. This was exhibited by the Science and Art Department at Bethnal Green from 1874 to 1878 , and at South Kensington from that date to 1885 ; and a catalogue raisonné was published by the Department, which went through two editions. After that, wishing to find a permanent home for it, where it would increase and multiply, I presented it to the University of Oxford, the University having granted $£ \mathrm{I} 0,000$ to build a museum to contain it. It is there known as the "Pitt-Rivers Collection," and is arranged in the same order as at South Kensington. Prof. Moseley has devoted much attention to the removal and re arrangement of it up to the time of his recent, but I trust only temporary, illness, which has been so great a loss to the University, and which has been felt by no one connected with it more than by myself, for whilst his great experience as a traveller and anthropologist enabled him to improve and add to it, he has at the same time always shown every disposition to do justice to the original collection. Since Prof. Moseley's illness it has been in the charge of $\mathrm{Mr} . \mathrm{H}$. Balfour, who, I am sure, will follow in the steps of his predecessor and former chief, and will do his best to enlarge and improve it. He has already added a new series in relation to the ornamentation of arrow stems, which has been published by the Anthropological Institute. It appears, however, desirable that the same system should be established in other places, and with that view I have for some time past been collecting the materials for a new museum, which, if I live long enough to complete it, I shall probahly plant elsewhere.

Before presenting the collection to Oxford I had offered it to the Government, in the hope that it might form the nucleus of a large educational museum arranged upon the system of develop. ment which I had adopted. A very competent Committee was appointed to consider the offer, which recommended that it should be accepted, but the Government declined to do so: one of the reasons assigned being that some of the authorities of the British Museum thought it undesirable that two ethnographical museums should exist in London at the same time; this, how. ever, entirely waives the question of the totally different objects that the two museums (at least that part of them which relates to ethnographical specimens) are intended to serve.

The British Museum, with its enormous treasures of art, is itself only in a molluscous and invertebrate condition of develop. ment. For the education of the masses it is of no use whatever. 
It produces nothing but confusion in the minds of those who wander through its long galleries with but little knowledge of the periods to which the objects contained in them relate. The necessity of storing all that can be obtained, and all that is presented to them in the way of specimens, precludes the possibility of a scientific or an educational arrangement.

By the published returns of the Museum it appears that there has been a gradual falling off in the number of visitors since 1882 , when the number was 767,873 , to 1887 , when it had declined to 501,256. This may be partly owing to the increased claims of bands and switchbacks upon public attention, but it cannot be owing to the removal of the Natural History Museum to South Kensington, as has been suggested, because the space formerly occupied ry those collections at Bloomsbury has been since filled with objects of greater general interest, and the galleries have been considerably enlarged.

The Science and Art Department at South Kensington has done much for higher education, but for the education of the masses it is of no more use than the British Museum, for the same reason, that its collections are not arranged in sequence, and its galleries are not properly adapted for such an arrangement. Besides these establishments, annual exhibitions on a prodigious scale have been held in London for many years, at an enormous cost, but at the present time not the slightest trace of these remain, and I am not aware of any permanent good that has resulted from them. If one-tenth of the cost of these temporary exhibitions had been devoted to permanent collections, we should by this time have the finest industrial museum in the world. Throughout the whole series of these annual temporary collections, only one, viz. the American department of the Fisheries Exhibition, was arranged upon scientific principles, and that was arranged upon the plan adopted by the National Museum at Washington. It appears probable from the experience of the present year that these annual exhibitions are on the decline. Large iron buildings have been erected in different places, some of which would meet all the requirements of a permanent museum. The Olympia occupies $3 \frac{1}{2}$ acres, the Italian Exhibition as much as 7 acres. There can be little doubt, I think, that the long avenues of potted meats and other articles of commonplace merchandise, which now constitute the chief part of the objects exhibited in these places, must before long cease to be attractive, and must be replaced by something else, and in view of such a change I venture to put in a plea for a National Anthropological Museum upon a large scale, using the term in its broadest sense, arranged stratigraphically in concentric rings. It is a large proposal, no doubt, but one which, considering the number of years I have devoted to the subject, I hope I shall not be thought presumptuons in subnitting for the consideration of the Anthropological Section of this Association.

The Palreolithic period being the earliest, would occupy the central ring, and having fewer varieties of form would require the smallest space. Next to it the Neolithic and Bronze Ages would be arranged in two concentric rings, and would contain, besides the relics of those periods, models of prehistoric monuments, bone caves, and other places interesting on account of the prehistoric finds that have been made in them. After that, in expanding order, would come Egyptian, Greek, Assyrian, and Roman antiquities, to be followed by objects of the Anglo-Saxon, Frankish, and Merovingian periods; these again in developmental outward expansion would be surrounded by mediæval antiquities, and the outer rings of all might then be devoted to showing the evolution of such modern arts as could be placed in continuity with those of antiquity.

In order that the best objects might be selected to represent the different periods and keep up the succession of forms which would constitute the chief object of the Museum, I would confine the exhibition chiefly to casts, reproductions, and models, the latter being, in my opinion, a means of representing primitive arts, which has not yet been sufficiently made use of, but which in my own small local museum at Farnham, Dorsetshire, I have employed to a considerable extent, having as many as twentythree models, similar to those now exhibited, of places in which things have been found within an area of two miles.

The several sections and rings would be superintended by directors and assistants, whose function it would be to obtain reproductions and models of the objects best adapted to display the continuity of their several arts and periods; and the arts selected for representation should be those in which this continuity could be most persistently adhered to. Amongst these the following might be named : pottery, architecture, house furniture, modes of navigation, tcols, weapons, weaving apparatus, painting, sculpture, modes of land transport and horse furniture, ornamentation, personal ornament, hunting and fishing apparatus, machinery, fortification, modes of burial, agriculture, ancient monuments, domestication of animals, toys, means of heating and of providing light, the use of food, narcotics, and so forth.

Miscellaneous collections calculated to confuse the several series, and having no bearing on development, should be avoided, but physical anthropology, relating to man as an animal, might find its place in the several sections.

I have purposely avoided in my brief sketch of this scheme giving unnecessary details. Any cut-and-dried plan would have to be greatly altered, according to the possibilities of the case, when the time for action arrived. My object is to ventilate the general idea of a large Anthropological Rotunda, which I have always thought would be the final outcome of the activity which has shown itself in this branch of science during the last few years, and which I have reason to believe is destined to come into being before long. In such an institution the position of each phase of art development shows itself at once by its distance from the centre of the space, and the collateral branches would be arranged to merge into each other according to their geographical positions.

The advantages of such an institution would be appreciated, not by anthropologists and archæologists only. It would adapt itself more especially to the limited time for study at the disposal of the working classes, for whose education it is unnecessary to say that at the present time we are all most deeply concerned. Although it is customary to speak of working men as uneducated, education is a relative term, and it is well to remember that in all that relates to the material arts they have, in the way of technical skill and handicraft, a better groundwork for appreciating what is put before them than the upper classes. That they are able to educate themselves by means of a well-arranged Museum, my own experience, even with the imperfect arrangements that have been at my command, enables me to testify. Anything which tends to impress the mind with the slow growth and stability of human institutions and industries, and their dependence upon antiquity, must, I think, contribute to check revolutionary ideas, and the tendency which now exists, and which is encouraged by some who should know better, to break drastically with the past, and must help to inculcate Conservative principles, which are urgently needed at the present time, if the civilization that we enjoy is to be maintained and to be permitted to develop itself.

The next subject to which I would draw your attention is the present working of the Act for the Preservation of Ancient Monuments, with the carrying out of which I have been intrusted during the last five years.

It is unnecessary to speak of the measures that have been taken in other countries which have preceded us in the work of protecting ancient monuments. Their system of land tenure and division of property is different from ours, and the same measures are not equally applicable.

In 1882 a Bill was passed through Parliament known as the Ancient Monuments Act, to enable those who desired to do so, to plare the ancient monuments belonging to them under the protection of the Government, and to make it illegal for future owners or others to destroy them : also to enable local magistrates to punish summarily, with a fine of $£ 5$ or imprisonment for one month, offences committed under the Act. No power is taken to compel any owner to place his monument under the Act, but provision is made for a small annual expenditure in order to preserve the monuments offered voluntarily by their owners. A schedule of certain monuments was attached to the Act, without the consent of the owners, merely to indicate the monuments to which the Act applied, but these, like any cthers, had to be voluntarily offered before the Government could accept them. Any other mnnuments not in the schedule could be accepted, but only after the offer of them had been laid forty days before Parliament, in order, I presume, that the country might not become charged with the preservation of monunients that were unworthy of protection.

In November 1882, I was asked by Lord Stalbridge, in a complimentary letter, written by desire of the Prime Minister, to under:ake the office of Inspector, intimating at the same time that my position as landowner would place $m e$ in a favourable position for dealing with other landowners to whom th.e monu- 
ments belonged, and I accepted the post, hoping to render a public service, not, perhaps, sufficiently considering the difficulties that I should have to encounter, and the amount of time that would have to be devoted to it.

A permissive Act naturally implies that there is some one in the country who desires to make use of it ; whereas, as a fact, no owner has voluntarily offered any monument to be put under the Act, except one to whom I shall refer again presently: all have had to be sought out and asked to accept the Act, and of the owners of scheduled tnonuments the larger number have refused.

Sir John Lubbock was chiefly instrumental in passing the Bill through Parliament, although in the condition in which it actually passed it was not his Bill. $\mathrm{He}$ had proposed to make the Act compulsory in the case of some of the more importan monuments, but the proposal had been overruled on the ground of its being an improper interference with private ownership.

lieing a member of the Liberty and Property Defence League, I have lately received a list of fifty-five measures which have been brought before Parliament in the session of 1888 , which that body have thought it desirable to oppose on account of their interference with private property, nearly every one of which would have dealt more hardly with the owners of property than the Ancient Monuments Act would have done had it been made compulsory. But all these measures have been proposed by members of Parliament with the view of catching the votes of particular constituencies, whereas the ancient monuments have no votes to give and very few people to vote for them. Sir John Lubbock, finding that the Act in its approved stage was purely permissive, and not believing, as he told me at the time, that anyone would voluntarily make use of it, naturally being unwilling to put his own prop erty at a disadvantage, by being the only person to come under it, at first refused to include his own monuments, and it was only after I had obtained others, and success appeared probable, that he consented to put Silbury Hill under the Act.

Finding myself involved in the matter, $I$ have done what I could to work it out, and with some success.

(To be continueils)

\section{THE INTERNATIONAL GEOLOGICAL CONGRESS.}

THE fourth session of the International Geological Congress began on Monday evening, September 17 , in the theatre of the University of London, Burlington Gardens; meetings were held throughout the week, and the session was formally closed on Saturday, September 22. In another form and in different places the Congress may be regarded as continuing throughout this week, for five excursions have been organized to various parts of England; those to North Wales and the Isle of Wight are largely attended, whilst smaller numbers have gone to East Anglia, to East Yorkshire, and to West Yorkshire.

At the opening meeting on Monday evening the Council was chosen as follows:--Hon. President: T. H. Huxley. President: J. Prestwich. Past Presidents : G. Capellini, E. Beyrich. Vice-Presidents: Germany, K. von Zittel Australia, *F. Liversidge ; Austria, M. Neumayr; Belgium, G. Dewalque ; Canada, T. Sterry Hunt; Denmark, *M Johnstrup ; Spain, J. Vilanova-y-Piera ; United States, P. Frazer ; France, A. de Lapparent; Great Britain, W. T. Blanford, A. Geikie, *T. McK. Hughes ; Hungary, J. von Szabó ; India, *H. B. Medlicott ; Italy, F. Giordano Norway, H. Reusch; Holland, K. Martin; Portugal, J F. N. Delgado ; Roumania, G. Stefanescu ; Russia, A. Inostranzeff; Sweden, O. Torell ; Switzerland, E. Renevier. General Secretaries: J. W. Hulke, W. Topley. Secretaries : C. Barrois, C. Fornasini, C. Le Neve Fuster, C. Gottsche, A. Renard, G. H. Williams. Treasurer F. W. Rudler. Other Members of the Council: T. G Bonney, A. Briart, E. Cohen, ${ }^{*}$ H. Credner, ${ }^{*}$ E. Dupont,
J. Evans, W. H. Flower, A. Gaudry, J. Gosselet, M. von Hantken, W. Hauchecorne, A. Heim, *J. Hooker, A. Issel, J. W. Judd, *R. Lepsius, C. Lory, *A. Michel-Lévy, T. Macfarlane, O. C. Marsh, E. von Mojsisovics, J. S. Newberry, S. Nikitin, *R. Owen, A. Pilar, F. von Richthofen, T. Schmidt, D. Stur, T. Tschernicheff, E. Van den Broeck, C. D. Walcott. (Those marked * were not present at the meeting.)

The President then delivered his address in French. An English translation of this has already appeared in NATURE. The meetings commenced each morning at 10.30 , and lasted till about I o'clock. Meetings of the Council were held each morning at 9.30. The procès-verbal of each meeting both of Council and Congress was printed, and was placed in the hands of members at the opening of the succeeding meeting. At various times meetings of the International Commissions on Nomenclature, and the Geological Map of Europe, and of various Committees appointed by the Council, were also held.

In the afternoons there were visits to the British Museum, in Bloomsbury, and to the Natural History Museum, South Kensington; also to Kew, Windsor and Eton, Erith and Crayford. In the evenings there were three receptions: on Monday, by the President of the Congress, in the library of the University, fitted up as a temporary Geological Museum; on Wednesday, by the Director-General of the Geological Survey, in the Museum of Geology, Jermyn Street; on Friday, by the President of the Geological Society, in the rooms of that Society.

Three invitations for the fifth meeting of the Congress in 1891 were received from America-from Philadelphia, New York, and Washington. Philadelphia was chosen. A Committee of American geologists was appointed to take such steps as it thought necessary to make the arrangements for this meeting. The Commitlee consisted of Messrs. J. Hall, Dana, Newberry, Frazer, Gilbert, Hunt, Marsh, and Walcott.

The general opinion is that the Congress was a complete success. So far as members go, this is evidently the case, as it was more largely attended than any previous meeting, both by home and by foreign geologists. As regards the number of members inscribed from the country in which the Congress meets, it is hot easy to make comparisons, because many join as members who have no claim to be considered geologists. No doubt this was more largely the case in London than at any previous meeting. But the numbers of foreign visitors may fairly be compared, and may be taken as affording a sufficient gauge of the rclative importance of each meeting. These stand as follows: Paris (1878), 110; Bologna (I881), 75 ; Berlin (1885), 92 ; London (1888), I42.

The success of such a gathering may, however, be reckoned on other lines, and here opinions on the subject may differ. Those who hold that the first duty of such a Congress is to formulate rules and to fix nomenclature may well feel some disappointment; for although excellent discussions took place, and the general feeling was often evident, no formal vote on any such subject was taken. It was generally felt that votes from such mixed assemblages have no value. They can only carry weight when taken on some fixed principle, not dependent upon the accidents of place and nationalities which vary from timeto time as the Congress meets in different countries. A Committee was formed to consider this matter. To its report, and to the general results of the Congress, we shall refer again next week. But upon one point there can be no difference of opinion: that is, the immense advantage resulting from the meeting together of men from different nations, engaged in similar pursuits, who can personally discuss subjects upon which they are at work. The friendships thus formed bear fruit long after the dicussions and votes of the formal meetings are forgotten. 